\title{
Pengaruh Jenis dan Rasio Maltodekstrin DE 10 dan Gum Arab Terhadap Sifat Fisik, Kimia, dan Stabilitas Mikroenkapsulasi Antosianin Ekstrak Etanol Umbi Ubi Jalar Ungu (Ipomoea batatas L.)
}

\author{
Oktavillariantika, A.A.I.A.S. ${ }^{*}$, N.P.U.S. Dewi ${ }^{1}$, N.L.P.K.M. Yanti ${ }^{1}$, C.I.S. Arisanti ${ }^{1}$
}

\author{
1Program Studi Farmasi Fakultas Matematika dan Ilmu Pengetahuan Alam Universitas Udayana, Jalan \\ Kampus Unud, Jimbaran, 80364 \\ * Penulis korespondensi: agungsicaa@yahoo.com \\ Received July 16, 2013; Accepted July 20, 2018
}

\begin{abstract}
ABSTRAK
Lipstik merupakan salah satu produk kosmetika dekoratif yang digemari oleh sebagian besar kaum wanita di Indonesia. Namun, ditahun 2014 BPOM menemukan bahwa beberapa merk kosmetika mengandung pigmen sintetis rhodamin B yang berbahaya serta mampu mengiritasi. Di sisi lain, Indonesia mengalami peningkatan produksi umbi ubi jalar ungu pada tahun 2013. Umbi ubi jalar ungu banyak mengandung senyawa berkhasiat, seperti antosianin yang berpotensi sebagai pewarna alami merah-keunguan (violet) baik pada makanan, obat, maupun kosmetika. Sayangnya, antosianin tidak stabil terhadap pemanasan tinggi, perubahan $\mathrm{pH}$, enzim, cahaya, ion logam, dan oksidasi. Tujuan dilakukan penelitian ini yaitu melindungi antosianin dari proses degradasi dan aplikasi penggunaan antosianin ekstrak umbi ubi jalar ungu termikroenkapsulasi terhadap stabilitas fisik terutama warna sediaan lipstik.

Metode yang dilakukan pada penelitian adalah microwave-assisted dengan bantuan pengeringan radiasi gelombang mikro. Rasio perbandingan bahan pelapis maltodekstrin DE 10; gum arab; kombinasi gum arab maltodekstrin (1:1) dengan ekstrak etanol umbi ubi jalar ungu sebesar $(2: 1) \%$ dan $(3: 1) \% \mathrm{~b} / \mathrm{b}$. Serbuk kering umbi ubi jalar ungu (Ipomoea batatas L.) diekstraksi dengan etanol $70 \%$ dalam suasana asam, dikentalkan. Ekstrak kental kemudian dimikroenkapsulasi. Formula optimum mikroenkapsulasi kemudian dijadikan lipstik dan diuji sifat fisisnya meliputi uji organoleptis dan homogenitas, kekuatan, uji $\mathrm{pH}$, titik lebur, dan stabilitas fisik.

Data dianalisis dengan metode Analysis of Variance (ANOVA) one-way, taraf kepercayaan 95\% dengan hasil uji sifat fisik mikroenkapsulasi pada formula III dihasilkan nilai kelembaban $2,44 \pm 0,03 \%$, ukuran partikel $\pm 304 \mu \mathrm{m}$, sertaefisiensi penjerapan tertinggi sebesar $51,78 \pm 0,06 \%$ dengan stabilitas yang lebih baik pada suhu $28^{\circ} \mathrm{C}$ dibandingkan dengan lima formula lainnya. Berdasarkan hasil penelitian, tidak ditemukan adanya pengaruh jenis dan rasio bahan pelapis kombinasi maltodekstrin dan gum arab $(2: 1) \% \mathrm{~b} / \mathrm{b}$ sebagai dinding mikroenkapsulasi pigmen antosianin umbi ubi jalar ungu terhadap warna sediaan lipstik.
\end{abstract}

Kata Kunci: Antosianin, Mikroenkapsulasi, Maltodekstrin, Gum arab, Lipstik

\begin{abstract}
Lipstick is one of the cosmetics products favored by most women in Indonesia. However, in 2014 BPOM found that some cosmetics brands contain rhodamine B synthetic pigments that are dangerous and capable of irritation. On the other hand, Indonesia has increased production of purple sweet potato tubers in 2013. Purple sweet potato tubers contain many nutritious compounds, such as anthocyanin which has potential as a natural red-purplish (violet) dye both in food, medicine, and cosmetics. Unfortunately, anthocyanins are unstable against high heating, $\mathrm{pH}$ changes, enzymes, light, metal ions, and oxidation. The purpose of this study is to protect anthocyanin from the degradation process and application of anthocyanin use of extract of sweet potato termic microencapsulation to physical stability, especially color of lipstick preparation.
\end{abstract}


The method used in the study was microwave-assisted with the help of microwave radiation drying. The ratio of maltodextrin DE 10 coatings; gum arabic; combination of maltodextrin gum arab (1: 1) with ethanol extract of sweet potato tuber of purple (2: 1)\% and (3: $1) \% \mathrm{w} / \mathrm{w}$. Dry purple sweet potato tuber powder (Ipomoea batatas L.) was extracted with 70\% ethanol in acidic atmosphere, thickened. The viscous extract is then micro-encapsulated. The microencapsulated optimum formula was then made into lipstick and tested for its physical properties including organoleptic and homogeneity tests, strength, $\mathrm{pH}$ test, melting point, and physical stability.

The data were analyzed by Analysis of Variance (ANOVA) one-way method, 95\% confidence level with the result of physical characteristic test of microencapsulation in formula III yielded humidity value $2,44 \pm 0,03 \%$, particle size $\pm 304 \mu \mathrm{m}, 51.78 \pm 0.06 \%$ with better stability at $28^{\circ} \mathrm{C}$ compared with the other five formulas. Based on the results of the study, there was no comparison and maltodextrin DE 10 and gum arab (2: 1)\% w / w as microencapsulated pigment wall of purple sweet potato tuber biocyanin against color of lipstick preparation.

Keywords: Anthocyanin, microencapsulation, maltodextrin DE 10, gum arabic lipstick

\section{PENDAHULUAN}

Studi Pemasaran Produk Kosmetik di Indonesia menyatakan bahwa pangsa pasar lipstik dalam 3 tahun terakhir semakin meningkat di kalangan usia muda 15 hingga 24 tahun. Diketahui pada tahun 2014 sebesar $59,3 \%$ dan tahun 2016, persentase penggunanya meningkat menjadi 68,4\%. Pewarna sebagai komponen utama memiliki daya tarik tersendiri dalam penggunaan lipstik, sehingga mutu dan keamanannya juga harus terjamin sesuai dengan persyaratan yang tercantum dalam Peraturan BPOM No. HK.00.05.4.1745 tentang Kosmetika. Tercatat dalam hasil pengawasan BPOM RI tahun 2014, ditemukan sebanyak 68 daftar merk kosmetika yang mengandung bahan-bahan berbahaya serta pigmen sintetis yang mampu mengiritasi, seperti Rhodamin B yang terdapat pada sediaan lipstik.

Antosianin merupakan golongan flavonoid yang tersebar pada bagian bunga, daun, hingga umbi tanaman (Purnomo dkk., 2014). Tercatat bahwa produksi salah satu tanaman penghasil antosianin, yakni ubi jalar ungu mencapai 2,3 juta ton per tahun di Indonesia (BPS, 2013). Menurut Husna (2013) kadar antosianin pada umbi ubi jalar ungu pekat mencapai $61,85 \%$ per 100 g. Warna khas yang dihasilkan antosianin adalah warna merah-keunguan (violet) yang cenderung stabil pada $\mathrm{pH}$ asam dan memiliki kelarutan baik pada pelarut polar (Winarti dkk., 2008). Oleh sebab itu, antosianin banyak ditemukan pada produk olahan makanan, kosmetik hingga kesehatan sebagai pewarna alami. Selain berfungsi sebagai pewarna alami, antosianin memiliki kandungan antioksidan tinggi dan berfungsi untuk mencegah radikal bebas sehingga dapat digunakan untuk pemakaian sediaan kosmetik, seperti krim anti aging (Dipahayu dkk., 2014). Beberapa penelitian lain menunjukkan adanya penggunaan antosianin sebagai pewarna alami kosmetika dekoratif, seperti lipstik dengan bahan aktif antosianin yang diperoleh dari ekstrak kental umbi ubi jalar ungu (Gumbara dkk., 2015). Namun, pada penelitian Purnomo dkk (2014) pigmen antosianin memiliki tingkat stabilitas yang kurang baik dalam pemanasan dan penyimpanan, sehingga mempengaruhi kualitas dan intensitas dari warna pigmen yang dihasilkan.

Mikroenkapsulasi menjadi alternatif dengan tujuan melindungi komponen senyawa dan mengurangi degradasi komponen bahan aktif. Metode microwave assisted atau pemanasan dengan bantuan gelombang mikro merupakan salah satu metode mikroenkapsulasi yang didasari atas kemampuan pelapisan bahan inti dengan bahan penyalut yang memiliki konstanta dielektrik yang berbeda (Abbasid and Rahimi, 2008 dalam Nawi et al., 2014). Bahan penyalut yang sering digunakan dalam proses mikroenkapsulasi antosianin diantaranya maltodekstrin dan gum arab (Ernawati dkk., 2014; Nawi et al., 2014). Keunggulan maltodekstrin dan gum arab 
adalah memiliki kemampuan dalam melindungi bahan dari proses oksidasi, mampu membentuk emulsi dengan viskositas yang rendah, mudah diperoleh dan lebih ekonomis. Penelitian Tonon et al. (2007) menunjukkan bahwa penyalutan dengan maltodekstrin DE 10 menghasilkan peningkatan kualitas warna dengan mikrostruktur lebih baik yang dibandingkan dengan ekstrak dan bubuk tanpa penyalut.

Berdasarkan hal tersebut, penulis tertarik menggunakan antosianin dari ekstrak umbi ubi jalar ungu sebagai alternatif untuk meminimalisir atau substitusi pewarna sintetis yang dapat mengiritasi dan berbahaya bagi konsumen dalam jangka panjang pada sediaan lipstik dengan meningkatkan stabilitas antosianin sebagai pewarna alami melalui teknik mikroenkapsulasi.

\section{BAHAN DAN METODE}

\subsection{Bahan dan Alat}

Bahan yang digunakan dalam penelitian, meliputi: Umbi ubi jalar ungu (desa Sembung, Kab. Badung, Bali), etanol 70\% (Bratachem), asam sitrat monohidrat (Bratachem), aqua DM (Bratachem), maltodekstrin DE 10 (Bratachem), gum arab (Bratachem), carnauba wax (Bratachem), paraffin wax (Bratachem), setil alcohol (Bratachem), adeps lanae(Bratachem), tween 80 (Bratachem), nipasol (Bratachem), oleum rosae (Bratachem), minyak jarak (Bratachem), kertas saring, kain kasa, kain satin.

\subsection{Metode}

\subsubsection{Penyiapan Ekstrak Kental Umbi Ubi Jalar Ungu}

Ekstrak kental umbi ubi jalar ungu dibuat berdasarkan pengembangan metode Husna dkk. (2013) dengan sortasi umbi jalar ungu yang diperoleh dari kabupaten Badung, Bali. Umbi dipotong kecil-kecil yang dikeringkan dalam oven (BINDER) selama 10 jam suhu $50^{\circ} \mathrm{C}$. Simplisia kering diserbuk dengan blander (Philips). Serbuk jadi di ekstraksi dengan etanol 70\% yang diasamkan dengan asam sitrat 3\% dengan perbandingan 85:15 (v/v). Maserasi dilakukan selama 24 jam dan diremaserasi sebanyak dua kali. Maserat yang diperoleh dipekatkan dengan vacuum rotary evaporator (BUCHI) pada suhu $40^{\circ} \mathrm{C}$ dengan tekanan \pm 70-80 mbar untuk menguapkan pelarut sehingga diperoleh ekstrak kental.

\subsubsection{Mikroenkapsulasi Antosianin dari Ekstrak Umbi Ubi Jalar Ungu}

Pembuatan mikroenkapsulasi

merupakan modifikasi dari proses penggerusan dan pengeringan dengan metode microwaveassisted dengan tahapan, homogenisasi antara bahan pelapis maltodekstrin DE 10 ; Gum arab; kombinasi Maltodekstrin DE 10 : Gum arab $(1: 1 \% \mathrm{~b} / \mathrm{b})$ dengan ekstrak etanol umbi ubi jalar ungu yang memiliki rasio perbandingan bahan pelapis dengan ekstrak sebesar (2:1) dan (3:1) \%b/b digerus dalam mortir selama 15 menit. Campuran homogen yang terbentuk dimasukkan ke dalam cawan petri (diameter $9 \mathrm{~cm}$ ) setinggi $0,5 \mathrm{~cm}$ dari dasar cawan petri, kemudian dimicrowave(SHARP R230R)selama 6 menit pada tingkat kepanasan 50\% (daya microwave sebesar 399 watt). Jarak cawan petri dari dasar piringan microwave setinggi $5,5 \mathrm{~cm}$. Setelah campuran yang terbentuk kering, dipanen dengan ayakan mesh 20 lalu disimpan dalam wadah yang terlindung dari cahaya dan kedap air. Kemudian di evaluasi sifat fisik dan kimia serta stabilitas mikroenkapsulasi untuk mengetahui formula optimum yang dihasilkan.

\subsubsection{Formulasi dan Pembuatan Lipstik}

Formula pembuatan lipstik yang digunakan merupakan modifikasi dari formula II dalam penelitian Gumbara dkk. (2015) seperti tertera pada tabel 2. Tahapan awal dengan penimbangan semua bahan menggunakan timbangan analitik sesuai dengan bobot pada formula dengan urutan : paraffin wax, carnauba wax, setil alkohol, dan adeps lanae kemudian dilelehkan di atas penangas air. Proses ini menghasilkan campuran A. Antosianin termikroenkapsulasi umbi ubi ungu, propilen glikol, tween 80, dan nipasol ditimbang. Kemudian antosianin termikroenkapsulasi dan propilenglikol dicampur hingga homogen dalam gelas beker. 
Tabel 2. Komposisi bahan penyusun sediaan lipstik

\begin{tabular}{cc}
\hline Bahan & Formula (gram) \\
\hline Carnauba wax & 0,45 \\
Paraffin wax & 0,3 \\
Setil alkohol & 0,24 \\
Adeps lanae & 0,24 \\
Propilenglikol & 0,3 \\
Tween 80 & 0,24 \\
Antosianin umbi & \\
ubi jalar ungu & 0,51 \\
termikroenkapsulasi & \\
Nipasol & 0,006 \\
Oleum rosae & 0,006 \\
Minyak jarak & 0,708 \\
\hline
\end{tabular}

Selanjutnya, dimasukkan tween 80 dan nipasol ke dalam mortir dan dihomogenkan (campuran B). Tahapan berikutnya, minyak jarak ditimbang, dimasukkan dalam mortir yang sudah dipanaskan. Campuran A yang sudah meleleh dituang, dihomogenkan dengan menggunakan stamper hangat. Setelah homogen, campuran B dituang dalam mortir yang sudah berisi minyak jarak dan campuran A kemudian dicampur hingga homogen. Seluruh campuran dituang ke dalam cawan porselin yang dipanaskan di atas penangas air kemudian diaduk menggunakan sendok stainless hingga leleh dan dicetak menggunakan cetakan lipstik. Cetakan dimasukkan ke dalam freezer (SHARP) yang bersuhu $1{ }^{\circ} \mathrm{C}$ dan ditunggu 10 menit (Gumbara dkk., 2015).

\subsubsection{Evaluasi Sifat Fisik Lipstik}

a. Uji Organoleptis dan Homogenitas

Lipstik dianalisis melalui pengamatan visual meliputi warna, aroma, dan bentuk.Uji homogenitas dilakukan dengan sejumlah tertentu sediaan lipstik dioleskan pada kaca yang transparan. Sediaan harus menunjukkan susunan yang homogen dan tidak terlihat adanya butir-butir kasar.

\section{b. Uji Kekuatan}

Lipstik diletakkan horizontal, pada jarak kira-kira $1 / 2$ inci dari tepi lipstik, digantungkan beban yang berfungsi sebagai penekan. Tiap 30 detik berat penekan ditambah (10 gram). Penambahan berat sebagai penekanan dilakukan terus menerus sampai lipstik patah, pada saat lipstik patah merupakan nilai kekuatan lipstiknya.

\section{c. Uji $\mathrm{pH}$}

$\mathrm{pH}$ meter (Mettler Toledo) dikalibrasi terlebih dahulu dengan menggunakan larutan dapar $\mathrm{pH}$ asam $(\mathrm{pH} 4,01)$ dan larutan standar $\mathrm{pH}$ netral $(\mathrm{pH} 7,00)$ hingga alat menunjukkan harga $\mathrm{pH}$. Kemudian elektroda dicuci dengan air suling, lalu dikeringkan dengan tisu. Sampel dibuat dalam konsentrasi 1\% yaitu ditimbang 1 $\mathrm{g}$ sediaan dan dilebur dalam gelas beker dengan $100 \mathrm{ml}$ air suling di atas penangas air. Setelah dingin kemudian elektroda dicelupkan dalam larutan tersebut, dan dibaca $\mathrm{pH}$ dari sediaan lipstik.

\section{d. Uji Titik Lebur}

Lipstik dimasukkan dalam oven (BINDER) dengan suhu awal $50^{\circ} \mathrm{C}$ selama 15 menit, diamati apakah lipstik meleleh atau tidak. Suhu dinaikkan $1^{\circ} \mathrm{C}$ setiap 15 menit dan diamati pada suhu berapa lipstik mulai melebur. Sediaan lipstik yang baik adalah sediaan lipstik dengan titik lebur dengan suhu di atas $50^{\circ} \mathrm{C}$.

\section{e. Uji Stabilitas Fisik}

Dilakukan dengan menguji karakteristik sediaan yang mencakup poin di atas. Kemudian sediaan disimpan pada temperatur ruangan dan temperatur $40^{\circ} \mathrm{C}$ selama 4 minggu. Pengujian dilakukan kembali terhadap sediaan untuk menentukan stabilitas sediaan.

\section{HASIL}

Hasil uji sifat fisik dan kimia dari mikroenkapsulasi antosianin umbi ubi jalar ungu dapat dilihat pada tabel 3.1. Hasil pengujian stabilitas mikroenkapsulasi antosianin umbi ubi jalar ungu dalam suhu $28^{\circ} \mathrm{C}$ dan $75^{\circ} \mathrm{C}$ selama 20 hari dapat dilihat pada tabel 3.2. Hasil evaluasi sifat fisik dari sediaan lipstik dengan pewarna alami antosianin umbi ubi jalar ungu termikroenkapsulasi dapat dilihat dalam tabel 3.3. Hasil uji stabilitas fisik pada pengamatan organoleptis sediaan lipstik selama 28 hari ditunjukkan dalam tabel 3.4. 
Tabel 3.1 Hasil Uji Sifat Fisik dan Kimia Mikroenkapsulasi

\begin{tabular}{|c|c|c|c|c|}
\hline Uji & Rasio & F I & F II & F III \\
\hline \multicolumn{5}{|l|}{ Organoleptis } \\
\hline & $(2: 1)$ & $\begin{array}{l}\text { Ungu kemerahan, } \\
\text { aroma khas gula, } \\
\text { bentuk serbuk } \\
\text { agregat }\end{array}$ & $\begin{array}{l}\text { Ungu, aroma khas } \\
\text { gula, bentuk } \\
\text { serbuk agregat }\end{array}$ & $\begin{array}{l}\text { Ungu kemerahan, } \\
\text { aroma khas gula, } \\
\text { bentuk serbuk }\end{array}$ \\
\hline Kelembaban (\%) & & $2,60 \pm 0,025$ & $3,30 \pm 0,035$ & $2,44 \pm 0,03$ \\
\hline Ukuran partikel & & $\pm 410 \mu \mathrm{m}$ & $\pm 448 \mu \mathrm{m}$ & $\pm 304 \mu \mathrm{m}$ \\
\hline Kelarutan & & $\begin{array}{l}\text { Sangat mudah } \\
\text { larut dalam air }\end{array}$ & $\begin{array}{l}\text { Sangat mudah } \\
\text { larut dalam air }\end{array}$ & $\begin{array}{l}\text { Sangat mudah larut } \\
\text { dalam air }\end{array}$ \\
\hline $\begin{array}{l}\text { Efisiensi } \\
\text { penjerapan (\%) }\end{array}$ & & $51,22 \pm 0,15$ & $39,73 \pm 0,15$ & $51,78 \pm 0,06$ \\
\hline
\end{tabular}

\begin{tabular}{|c|c|c|c|c|}
\hline Uji & Rasio & F IV & F V & F VI \\
\hline \multicolumn{5}{|l|}{ Organoleptis } \\
\hline & $(3: 1)$ & $\begin{array}{l}\text { Ungu, aroma khas } \\
\text { gula, bentuk } \\
\text { serbuk }\end{array}$ & $\begin{array}{l}\text { Ungu muda, } \\
\text { aroma khas gula, } \\
\text { bentuk serbuk }\end{array}$ & $\begin{array}{l}\text { Ungu, aroma khas } \\
\text { gula, bentuk serbuk }\end{array}$ \\
\hline Kelembaban $(\%)$ & & $2,06 \pm 0,045$ & $3,20 \pm 0,03$ & $2,03 \pm 0,025$ \\
\hline Ukuran partikel & & $\pm 178 \mu \mathrm{m}$ & $\pm 114 \mu \mathrm{m}$ & $\pm 100 \mu \mathrm{m}$ \\
\hline Kelarutan & & $\begin{array}{l}\text { Sangat mudah } \\
\text { larut dalam air }\end{array}$ & $\begin{array}{l}\text { Sangat mudah } \\
\text { larut dalam air }\end{array}$ & $\begin{array}{l}\text { Sangat mudah larut } \\
\text { dalam air }\end{array}$ \\
\hline $\begin{array}{l}\text { Efisiensi } \\
\text { penjerapan (\%) }\end{array}$ & & $50,67 \pm 0,19$ & $41,72 \pm 0,11$ & $47,55 \pm 0,21$ \\
\hline
\end{tabular}

Keterangan:

*Rasio (2:1) F I= Formula I Maltodekstrin DE 10 : Ekstrak etanol umbi ubi jalar ungu

*Rasio (2:1) F II= Formula II Gum arab : Ekstrak etanol umbi ubi jalar ungu

* Rasio (2:1) F III= Formula III (Maltodekstrin DE 10 : Gum arab) : Esktrak etanol umbi ubi jalar ungu

*Rasio (3:1) FIV=Formula IV Maltodekstrin DE 10 : Ekstrak etanol umbi ubi jalar ungu

*Rasio (3:1) F V = Formula V Gum arab : Ekstrak etanol umbi ubi jalar ungu

*Rasio (3:1) F VI=Formula VI (Maltodekstrin DE 10 : Gum arab) : Esktrak etanol umbi ubi jalar ungu 
Tabel 3.2 Hasil Uji Stabilitas Mikroenkapsulasi (Suhu $28^{\circ} \mathrm{C}$ dan $75^{\circ} \mathrm{C}$ )

\begin{tabular}{|c|c|c|c|c|}
\hline Suhu & Formula & $\mathbf{k}$ & $\mathrm{t}^{1 / 2}$ (jam) & $\mathrm{t}_{90}$ (jam) \\
\hline \multirow{6}{*}{$28^{\circ} \mathrm{C}$} & I & 0,0537 & 309,7207 & 46,927 \\
\hline & II & 0,0497 & 334,6479 & 50,704 \\
\hline & III & 0,0469 & 354,6269 & 53,731 \\
\hline & IV & 0,0516 & 322,3256 & 48,837 \\
\hline & V & 0,0723 & 230,0415 & 34,854 \\
\hline & VI & 0,0797 & 208,6826 & 31,618 \\
\hline \multirow{3}{*}{$75^{\circ} \mathrm{C}$} & IV & 0,2618 & 63,52941 & 9,625 \\
\hline & V & 0,1493 & 111,3999 & 16,878 \\
\hline & VI & 0,1292 & 128,7307 & 19,504 \\
\hline
\end{tabular}

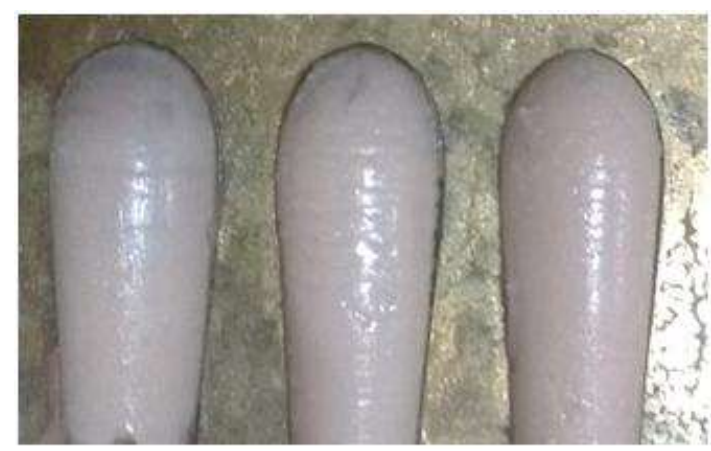

Gambar 1. Lipstik dengan pewarna antosianin umbi ubi jalar ungu termikroenkapsulasi.

Tabel 3.3 Hasil Uji Sifat Fisik Lipstik dengan Pewarna Mikrokapsul Formula III dengan Pembanding Lipstik Merk (W).

\begin{tabular}{|c|c|c|c|}
\hline Parameter & Lipstik antosianin & Lipstik W & Pustaka \\
\hline $\begin{array}{l}\text { Organoleptis } \\
\text { (warna, aroma, } \\
\text { dan bentuk) }\end{array}$ & $\begin{array}{l}\text { Peach, khas ol.rosae, } \\
\text { torpedo dan halus }\end{array}$ & $\begin{array}{l}\text { Pink, tidak berbau, } \\
\text { torpedo dan halus }\end{array}$ & - \\
\hline Homogenitas & Tidak homogen & Homogen & - \\
\hline Kekuatan & 500 gram & 600 gram & - \\
\hline $\mathrm{pH}$ & $4,19 \pm 0,03$ & 5 & $\begin{array}{l}\text { Rentang pH 4-6 (Ali \& } \\
\text { Yosipovitch, 2013). }\end{array}$ \\
\hline Titik lebur & $65,33 \pm 0,57^{\circ} \mathrm{C}$ & $63^{\circ} \mathrm{C}$ & $\begin{array}{l}>50^{\circ} \mathrm{C} \text { (Vishmakarna et } \\
\text { al., 2011). }\end{array}$ \\
\hline
\end{tabular}

Tabel 3.4 Hasil Uji Stabilitas Sediaan Lipstik Selama 28 Hari

\begin{tabular}{lccccccccccc}
\hline Parameter & \multicolumn{10}{c}{ Lama Pengamatan (Hari Ke-) } \\
\cline { 2 - 11 } & \multicolumn{1}{c}{$28^{\circ} \mathrm{C}$} & \multicolumn{7}{c}{4} \\
\cline { 2 - 9 } & 0 & 7 & 14 & 21 & 28 & 0 & 7 & 14 & 21 & 28 \\
\hline Warna & +++ & +++ & +++ & +++ & +++ & +++ & +++ & +++ & +++ & +++ \\
Aroma & +++ & +++ & +++ & ++ & ++ & +++ & +++ & +++ & ++ & + \\
Bentuk & +++ & +++ & +++ & +++ & +++ & +++ & +++ & +++ & +++ & +++ \\
\hline
\end{tabular}
Keterangan:

$*+++=$ warna peach, aroma khas ol. rosae, bentuk torpedo halus.

$*++=$ warna sedikit pudar, sedikit beraroma khas ol. rosae, berubah bentuk

*+ = warna pudar, tidak ada aroma khas ol. rosae, berubah bentuk 
Jurnal Farmasi Udayana, Vol 7, No.1, Tahun 2018, 19-27

\section{PEMBAHASAN}

Berdasarkan hasil uji sifat fisik dan kimia diperoleh formula III sebagai formula optimum yang memiliki sifat fisik dan kimia yang baik dengan nilai kelembaban sebesar $2,44 \pm 0,03 \% \mathrm{~b} / \mathrm{b}$, ukuran partikel $\pm 304 \mu$ mdan memiliki efisiensi penjerapan paling tinggi sebesar $51,78 \pm 0,06 \% \mathrm{~b} / \mathrm{v}$. Hasil uji stabilitas pada suhu $28^{\circ} \mathrm{Cyang}$ paling baik diantara semua formula ditunjukkan oleh formula III yang dapat mempertahankan kadar antosianin sebanyak $\quad 90 \%\left(\mathrm{t}_{90}\right) \quad$ selama 53,731 jam.Walaupun formula VI telah mampu menunjukkan stabilitas yang baik, pada perlakuan suhu $75^{\circ} \mathrm{C}$ selama 20 haridenganmempertahankan kadar antosianin hingga 90\% (t ton$_{0}$ selama 19,504 jam.Hasil uji statistik dengan ANOVA-one way menunjukkan bahwa jenis dan rasio bahan pelapis berpengaruh signifikan terhadap nilai kelembaban dan efisiensi penjerapan mikrokapsul, yang ditunjukkan dengan nilai $(\mathrm{P}<0,05)$. Uji LSD juga menunjukkan bahwa jenis dan rasio bahan pelapis berpengaruh secara signifikan terhadap nilai kelembaban, kecuali pada Formula IV dan VI.

Kelembaban dipengaruhi oleh struktur maltodekstrin DE 10 dan gum arab yang mengandung gugus -OH (hifrofilik), sehingga dengan cepat dapat menyerap air di udara selama proses pengeringan. Jumlah gugus hidrofilik yang ada dalam struktur masingmasing bahan pelapis menentukan variasi adsorpsi air. Menurut Tonon et al. (2010) maltodekstrin DE 10 memiliki sedikit gugus hidrofilik yang menyebabkan adsorpsi air di udara sekitarnya lebih sedikit dibandingkan dengan gum arab. Efisiensi penjerapan yang baik menunjukkan kemampuan bahan pelapis dalam menjerap hingga melindungi inti dari pengaruh lingkungan. Formula III dengan rasio bahan pelapis : inti $(2: 1) \% \mathrm{~b} / \mathrm{b}$ menghasilkan efisiensi penjerapan tertinggi sebesar $51,78 \pm 0,06 \%$. Formula IV dan VI memiliki stabilitas yang lebih baik dikarenakanadanya penggunaan maltodekstrin sebagai penstabil yang dapat mengurangi mobilitas reaktan (Chronakis, 1998; Duangmal et al. 2008).
Berdasarkan hal tersebut, formula III merupakan formula yang paling tepat digunakan dalam formulasi sediaan lipstik. Pembuatan lipstik dengan formula III menghasilkan sifat fisik, meliputi organoleptis, kekuatan, $\mathrm{pH}$ dan titik lebur yang memenuhi persyaratan SNI kosmetika yang beredar dipasaran. Sedangkan uji homogenitas menghasilkan lipstik dengan warna tidak seragam, sehingga belum memenuhi persyaratan. Ketidakseragaman warna dikarenakan sifat dari maltodekstrin DE 10, gum arab dan antosianin yang bersifat polar dan banyak mengandung gugus hidrofilik, sehingga basis yang bersifat lipofilik sulit menyatu dengan mikrokapsul yang bersifat hidrofilik(Nurhaida dkk., 2017).

Pengujian stabilitas dilakukan untuk melihat stabilitas fisik dari sediaan lipstik pada kondisi suhu yang berbeda. Sampel sediaan lipstik disimpan pada dua taraf suhu yang berbeda, yakni suhu ruang $\left(28^{\circ} \mathrm{C}\right)$ dan suhu dipercepat $\left(40^{\circ} \mathrm{C}\right)$ selama 28 hari. Selama periode penyimpanan, dilakukan pengamatan uji organoleptis yang meliputi, warna, aroma dan bentuk dengan waktu pengujian tiap 7 hari sekali. Pengenalan awal sediaan lipstik secara objektif dapat ditinjau dari parameter organoleptis berupa warna, aroma, dan bentuk. Hasil pengamatan secara organoleptispada sediaan lipstik terlihat bahwa sediaan stabil secara fisik pada penyimpanan suhu ruang $\left(28^{\circ} \mathrm{C}\right)$ dan suhu dipercepat $\left(40^{\circ} \mathrm{C}\right)$ selama 21 hari. Pada pengujian stabilitas ditemukan ketidakstabilan bau pada suhu $40^{\circ} \mathrm{C}$ di hari ke21 hingga 28, hal ini disebabkan oleh sifat oleum rosae yang menguap selama proses penyimpanan hingga pemanasan dalam jangka waktu yang lama (Suryanto dan Purba, 2012).

\section{KESIMPULAN}

Berdasarkan penelitian yang telah dilakukan, dapat disimpulkan bahwa pigmen warna antosianin umbi ubi jalar ungu termikroenkapsulasi dengan jenis bahan pelapis kombinasi maltodekstrin DE 10 dan gum arab dengan rasio (2:1) \%b/b tidak berpengaruh pada warna lipstik. 


\section{UCAPAN TERIMAKASIH}

Penulis mengucapkan terimakasih kepada seluruh pihak yang terlibat dalam penelitian ini.

\section{DAFTAR PUSTAKA}

Abbasi, S. and S. Rahimi. 2008. Microwaveassisted Encapsulation of Citric Acid Using Hydrocolloids. Int. J. Food Sci. Tecbnol. 43:1226-1232.

Ali, S.M., and Yosipovitch G. 2013.Skin pH : From Basic Science to Basic Skin Care, Acta Derm Venerol, 93, 261.

BPS. 2013. Luas Panen, Produktivitas dan Produksi Ubi Jalar Menurut Provinsi(cited 1Oktober 2017) Available from:URL:http://www.bps.go.id.

Chronakis, I. S. 1998. On The Molecular Characteristics, Compositional Properties, and Structural-Functional Mechanism of Maltodextrins: A Review. Crit. Rev. Food Sci. Nutr. 38(7):599-637.

Dipahayu, D., W. Soeratri, M. Agil. 2014. Formulasi Krim Antioksidan Ekstrak Etanol Daun Ubi Jalar Ungu (Ipomea batatas (L.) Lamk) sebagai Anti Aging. Pharm Sci Res 1(3): 166-179.

Duangmal, K., B. Saicheua, and S. Sueeprasan. 2008. Colour Evaluation of FreezeDried Roselle Extract As A Natural Food Colorant In A Model System of A Drink. LWT 41:1437-1445.

Ernawati, U.R., L.U. Khasanah, dan R.B.K. Anandito. 2014. Pengaruh Variasi Nilai Dextrose Equivalents (DE) Maltodekstrin Terhadap Karakteristik Mikroenkapsulan Pewarna Alami Daun Jati (Tectona grandis L.f.). Jurnal Teknologi Pertanian 15(2): 111-120.

Gumbara, Y.T., M. Murrukmihadi, dan S. Mulyani. 2015. Optimasi Formula Sediaan Lipstik Ekstrak Etanolik Umbi Ubi Jalar Ungu (Ipomea batatas L.) dengan Kombinasi Basis Carnauba $W a x$ dan Parafin Wax Menggunakan Metode SLD
(Simplex Lattice Design). Majalah Farmaseutik 11(3):336-345.

Husna, N. E., M. Novita, S. Rohaya. 2013. Kandungan Antosianin dan Aktivitas Antioksidan Ubi Jalar Ungu Segar dan Produk Olahannya. Agritech 33(3): 296302.

Mahdavi, S.A., S.M. Jafari, E. Assadpoor, and D. Dehnad. 2016. Microencapsulation Optimization of Natural Anthocyanins With Maltodextrin, Gum Arabic and Gelatin. International Journal of Biological Macromolecules 85:379-385.

Nawi, N.M., I. I. Muhamad, and A.M. Marsin. 2015. The Physicochemical Properties of Microwave-assisted Encapsulated Anthocyanins from Ipomoea batatas as Affected by Different Wall Materials. Food Science \& Nutrition Original Research 3(2):91-99.

Nurhaida, A., H. Susilo, dan B. L. Sari. 2017. Aktivitas Antioksidan Sediaan Lipstik dengan Pewarna Alami Ekstrak Buah Naga Super Merah (Hylocereus costaricensis L.). Diakses di perpustakaan.fmipa.unpak.ac.id tanggal 25 Juni 2018.

Purnomo, W., L. U. Khasanah, dan R. B. K. Anandito. 2014. Pengaruh Ratio Kombinasi Maltodekstrin, Karangenan dan Whey Terhadap Karakteristik Mikroenkapsulan Pewarna Alami Daun Jati (Tectona grandis L.f.). Jurnal Aplikasi Teknologi Pangan 3(3): 121-129.

Suryanto, N. H. dan D. Purba. 2012. Efek Pelembab Minyak Biji Bunga Matahari dalam Sediaan Krim Tangan. Journal of Pharmaceutics and Pharmacology. 1(1): 6369.

Tonon, R.V., C. Brabet, dan M.D. Hubinger. 2010. Anthocyanin Stability and Antioxidant Activity of Spray-Dried Acai (Euterpe Oleracea Mart.) Juice Produced With Different Carrier Agents. Food Research International, 43(3): 907-914. 
Oktavillariantika dkk.

Vishwakarma, B., Dwivedi, S., Dubey, K., and Joshi, H. 2011. Formulation and Evaluation of Herbal Lipstick.International Journal of Drug Discovery and Herbal Research 1(1):18-19.
Winarti, S., U. Sarofa, dan D. Anggrahini. 2008. Ekstraksi dan Stabilitas Warna Ubi Jalar Ungu (Ipomea batatas L.) sebagai Pewarna Alami. Jurnal Teknik Kimia 3(1): 207-214. 